\title{
Energy Colonialism Powers the Ongoing Unnatural Disaster in Puerto Rico
}

\author{
Catalina M. de Onís* \\ Civic Communication and Media, Willamette University, Salem, OR, United States
}

On September 20, 2017, Hurricane María made landfall in Puerto Rico. Blasting the Caribbean archipelago with 155-mile/h winds, this, in many ways, unnatural disaster exposed the brutal consequences of energy colonialism and an extractivist economy, as well as ongoing and increasing advocacy for decentralized solar infrastructure by many local residents and other renewables supporters. This paper argues that acknowledging colonial power relations and their consequences is essential for studying the interplay of energy systems, environments, and actors. To support this claim, this essay outlines Puerto Rico's history as a US colony by focusing on key policies and their implications; examines openings for and barriers to decentralized, community solar in Puerto Rico; and concludes by discussing future research directions on just energy transitions and the imperative of uprooting colonialism and agitating for community self-determination

OPEN ACCESS

Edited by:

Andrea M. Feldpausch-Parker, State University of New York College

of Environmental Science and Forestry, United States

Reviewed by:

Samantha Senda-Cook Creighton University, United States Jennifer Peeples, Utah State University, United States

${ }^{*}$ Correspondence:

Catalina M. de Onís cdeonis@willamette.edu

Specialty section: This article was submitted to Science and Environmental Communication, a section of the journal Frontiers in Communication

Received: 31 October 2017 Accepted: 11 January 2018

Published: 29 January 2018

Citation:

de Onís CM (2018) Energy Colonialism Powers the Ongoing Unnatural Disaster in Puerto Rico.

Front. Commun. 3:2. doi: 10.3389/fcomm.2018.00002 and energy justice in these transformations.

Keywords: disaster capitalism, energy colonialism, energy justice, Hurricane María, Puerto Rico

On September 20, 2017, Hurricane María rattled Puerto Rico. Weakened by a $\$ 73$-billion debt crisis, outdated infrastructure, and Hurricane Irma, which skirted the Caribbean archipelago just weeks before, the US unincorporated territory could not sustain the damage caused by the nearly Category 5 María. This most unnatural disaster accelerated the already launched collision of Puerto Rico's entwined economic, energy, and environmental crises (Bonilla, 2017; de Onís, 2017a; Lloréns et al., 2018). As of this writing, about 40 percent of households are still without electricity, and those that have power often do not have consistent access. For months after the storm, many people also lacked potable water, which resulted in some residents drinking from superfund and other contaminated sites (Hand, 2017). Meanwhile, the death toll linked to the storm exceeds one-thousand people (Center for Investigative Journalism, 2017).

Examining this still-unfolding humanitarian crisis requires studying Puerto Rico's historical and present-day experiences with colonialism, especially energy colonialism. This extractivist system and discourse marks certain places and peoples as disposable by importing and exporting logics and materials to dominate various energy forms, ranging from humans to hydrocarbons (Atiles-Osoria, 2014; de Onís, 2017a; McDermott, 2017). During the last 4 years, I have studied how Puerto Ricoa US colony since 1898-has been exploited as a sacrifice zone for empire building and experimentation, corporate greed, and toxic energy projects (Bullard, 1993). ${ }^{1}$ I also have encountered many social movement actors and energy studies scholars engaged in long-time struggles for alternatives to imported fossil fuels and centralized systems that deny community member control over their own energy futures. To examine the pre- and post-María milieu, this essay outlines Puerto Rico's history as a US colony by focusing on key policies and their consequences; examines openings for

${ }^{1}$ Here, I diverge from the "US unincorporated territory" designation to name Puerto Rico's political status for what it is: a US colony. 
and barriers to decentralized solar energy in Puerto Rico; and concludes by discussing directions for future research on energy transitions and the importance of foregrounding self-determination and energy justice for those most impacted by these projects and policies. ${ }^{2}$

\section{ON COLONIALISM, CARBON, AND CORRUPTION}

Prior to Hurricane María, entwined economic, environmental, and energy exigencies set the scene for a perfect storm of devastation. While several policies played a role in and are important for understanding Puerto Rico's contemporary situation, I focus on three that epitomize Puerto Rico's colonial dilemma. These are: the Jones Act, Operation Bootstrap, and the Puerto Rico Oversight Management and Economic Stability Act (PROMESA).

The 1920 Jones Act, also known as the Merchant Marine Act, requires that all goods entering Puerto Rico's ports arrive on US-made, US-staffed, and US-flag-carrying ships, an arbitrary policy imposed on the so-called "Rich Port." This Act has choked hurricane relief efforts, as much-needed supplies have sat in local waters waiting to be distributed or have been sent back to their points of origin. While President Trump lifted the Jones Act for 10 days, because of public pressure, this temporary waiver did little to alleviate the burdens created by this economic dependency and its high financial and other costs.

Another twentieth century policy that continues to haunt Puerto Rico is Operation Bootstrap. Beginning in the 1940s, this industrialization-by-invitation initiative implemented loopholes and tax incentives, thus positioning Puerto Rico as a destination for wealthy investors and corporate polluters, including the pharmaceutical and fossil fuel industries (Berman Santana, 1996). This form of "petrochemical colonialism" targets precarious communities that are in contemporary times exploited not by slave owners but "by the petrochemical industry executive as the new 'master' and 'overseer"' (Bullard, 1993, p. 13).

Puerto Rico's current energy mix continues to be shaped by this heavy carbonization initiative. According to the Puerto Rico Energy Commission (PREC, 2016), petroleum, natural gas, coal, and renewables constitute $62,18,17$, and 3 percent of Puerto Rico's energy mix, respectively. Those numbers translate into a reliance on imported fossil fuels for 97 percent of the Big Island's energy needs, causing residents to pay two to three times more than the average US household on their electricity bills.

\footnotetext{
${ }^{2}$ Informed by environmental and climate justice, energy justice is concerned with how People of Color and low-income communities are impacted by global climate disruption, energy poverty, energy vulnerability, and decarbonization (i.e. transitioning from high-carbon energy sources, such as petroleum and coal, to low-carbon energies, such as wind and solar). Energy justice also struggles against the exploitation of indigenous lands and communities for high-risk and toxic energy development, from nuclear to fracked gas, and also recognizes the importance of sustainable jobs in the renewable energy sector and achieving energy security and sovereignty in relation to infrastructure, distribution, and access. Thus, this movement and discourse strives for direct community engagement to advance sustainable practices, including considerations of how, where, and for/by whom energy is produced, distributed, consumed, maintained, and disposed of (Sovacool \& Dworkin, 2014).
}

Accompanying this energy backdrop, in 2016, President Barack Obama and the US Congress approved PROMESA, which granted unbridled power for "managing" the debt crisis to an undemocratically elected control board, locally called "la junta." Numerous individuals and groups have criticized PROMESA for, its neoliberal austerity agenda and sweeping oversight abilities. Board members have proposed, cutting retirement pensions, closing numerous K-12 schools, gutting funding for the public university system, and fast-tracking "critical" energy projects (PROMESA, 2016). In response, many community members have rejected the legislation and its colonial impositions, with slogans such as "se acabaron las promesas," translated as "promises are over," and "la gente antes que la deuda," or "people before debt."

The debt situation and other colonial efforts to ensure Puerto Rico's economic dependency have yielded dire consequences for local residents. Prior to the 2017 hurricane season, about half of Puerto Ricans lived in poverty, faced high unemployment rates, and had a per capita income of about $\$ 15,000$ per year (Bureau of Labor Statistics, 2017). Now the situation is much, much worse. Personal financial distress is tied to the debt crisis, a result of risky municipal bond sales, as well as other monetary dealings that have burdened residents with financial hardships, while benefiting wealthy investors (Kolhatkar, 2017).

In response to a lack of resources and adequate recovery efforts, more than 300,000 residents have left the archipelago for Florida alone since María, and those numbers are expected to grow in the months and years ahead (Bonilla, 2018). Prior to the storm, Puerto Rico was home to 3.4 million people, a number persistently eroded in the past decade, as Puerto Ricans, who are US citizens, moved north in search of more livable conditions (Duany, 2002; Centro, 2017).

Human movements are not the only changes unfolding in this US colony. Puerto Rico's bankrupt public power utility, the Puerto Rican Electric Power Authority (PREPA), faces privatization and is experiencing substantial challenges in restoring electricity to the Big Island. Despite assurances from local government and power authority officials insisting that electricity would be restored 3 months after the storm, portions of Puerto Rico likely will remain without power until May 2018-or later (Robles and Mazzei, 2017). One reason for this delay is because of poorly selected and negotiated contracts with inexperienced companies with questionable ties.

The Puerto Rican government's three-million-dollar agreement to restore its decimated grid with Montana-based Whitefish Energy sounded alarms. New to the energy sector, the company employed only a few people at the time of the contract signing and had no experience with a project the size required for Puerto Rico (Whitefish Energy, 2017). Critics of the deal were quick to point out that US Secretary of the Interior Ryan Zinke and Whitefish Energy are from the same Montana town, and the company formerly employed Zinke's son (Geiling, 2017; Goldman, 2017). Amid growing concerns about local and US government and corporate corruption, the Puerto Rico-Whitefish agreement was canceled in late October 2017 (Noticel, 2017). Another two-million-dollar contract with Oklahoma-based, fossil-fuel energy company Cobra also stirred controversy. These two deals exemplify disaster capitalism, as politicians and others 
mobilize shock to curtail agency and resistance to advance a neoliberal, free-market agenda that works to silence alternative perspectives and pathways (Klein, 2007).

Those still without power are frustrated by the delays but also have become accustomed to PREPA's mismanagement. Prior to María, costly electric bills, frequent and widespread outages, environmental pollution, human health harms, and the denial of local community control over residents' own energy futures were the norm in Puerto Rico (Wanzer-Serrano, 2015). This situation has made some large-scale renewable energy proposals particularly appealing.

In the days following the hurricane, Puerto Rican Governor Ricardo Rosselló Nevares and Tesla founder and CEO Elon Musk exchanged tweets about collaborating to address the colony's energy emergency. Supporters of the potential partnership celebrated these emergent plans for installing huge Tesla powerpacks, while critics cautioned that a deal with Musk only serves to advance green capitalism, exemplifies the white savior trope, and positions Puerto Rico as a site for experimentation by the United States (Cummins, 2017; Santiago et al., 2017).

These aforementioned contracts elucidate efforts by Puerto Rican officials and US-based corporations to rebuild the Big Island's power grid, rather than to dramatically transform it, by shifting to small-scale, decentralized solar energy projects organized and maintained at the local community level. Such a departure would revolutionize the colony's current energy culture and disrupt inequitable power dynamics. For some in Puerto Rico, this urgent shift has been central to their daily work for years.

\section{ENACTING ENERGY DEMOCRACY}

Academics at the University of Puerto Rico Mayagüez (UPRM) have developed two institutes for advancing energy democracy on the Big Island: the Instituto Tropical de Energía, Ambiente $y$ Sociedad (ITEAS, or the Tropical Institute of Energy, Environment and Society), and the Instituto Nacional de Energía y Sostenibilidad Isleña (INESI, or the National Institute of Island Energy and Sustainability). ITEAS and INESI were created by an interdisciplinary team of professors, who sought to disrupt Puerto Rico's electric energy system and the "energy status quo social network" by creating a framework for a sustainable energy ethic committed to deliberation and decision-making among diverse actors, not only engineers and economists (personal communication, Marla Pérez Lugo and Cecilio Ortiz García, May 21, 2015).

INESI was established in May 2015 and strives to create a sustainable and independent energy system. According to the Institute's website, Puerto Rico's energy transition requires "just and transparent decisional processes and citizens capable of participating actively by means of adaptive and collaborative learning, contributing to the social wellbeing of Puerto Ricans as much to this generation as to future ones." Interested in being part of this collaborative transition process post-María, INESI members crafted letters addressed to Rosselló Nevares and Lieutenant General Jeffrey Buchanan, who was leading disaster relief efforts. In our October 16 phone conversation, Dr. Marla Pérez Lugo, one of the INESI's steering committee members, expressed that she and her colleagues felt compelled to draft the letters, in response to dominant discourses about "rebuilding," rather than radically transforming, Puerto Rico's current energy system. Pérez Lugo explained: "We got worried, as the system as it was is what brought us here." In their letter to the governor, INESI members contend: "La sostenibilidad de nuestro sistema eléctrico depende del uso descentralizado de nuestros recursos locales (como la conservación, la eficiencia, los sistemas solares en los techos y almacenamiento en casas y edificios) y de una nueva gobernanza justa, desconcentrada, colaborativa, participativa, y democrática." “"The sustainability of our electric system depends on the decentralized use of our local natural resources (like conservation, efficiency, solar systems on roofs, and placed on houses and buildings) and a new just, deconcentrated, collaborative, participative, and democratic government."

In another letter addressed to Rosselló Nevares and Musk, the authors note the substantial resources and insights that the INESI team has developed while examining and participating in energy conversations and decisions in Puerto Rico. They offer: "We stand ready to help... with over 90 contributing faculty covering 23 disciplines, across the 11 campuses of the University of Puerto Rico (UPR), INESI offers unparalleled expertise in the technical, economic, and social dimensions of energy transitions." Whether the services extended by this interdisciplinary academic team will be acknowledged and mobilized remains to be seen, as these energy researchers have been excluded from key conversations about the Big Island's energy future (de Onís, 2017b).

Despite this lack of institutional recognition, several examples of solar energy advocacy have emerged at the local level. These efforts resonate with the \#PuertoRicoSeLevanta (translated as Puerto Rico rises up or lifts itself up) hashtag circulating on- and off-line. For example, INESI has been working on an emergent energy access mapping effort and a project in the mountain town of Jayuya, called Jayuya Solar. Also in the mountainous regions of the Big Island, which were especially hard hit by the storm and remain isolated, Casa Pueblo, led by Goldman Environmental Prize winner Alexis Massol-González, has been working to deliver solar lanterns to the municipalities of Adjuntas, Utuado, and Jayuya (Moya, 2017). Casa Pueblo has a long history of renewable energy advocacy, exemplified by its headquarters building, which installed a solar system in 1999 (Casa Pueblo, 2016). Resilient Power Puerto Rico is supporting local efforts by delivering solar generators to the most under-resourced areas of Puerto Rico and plans to widen its reach to advance solar energy and disaster preparedness throughout the Big Island (Resilient Power Puerto Rico, 2017).

As yet another example, collaborators on the Coquí Solar community project persist in their multi-year campaign to develop sustainable, renewable energy in El Coquí, a town in southern Puerto Rico. Near Jobos Bay, Coquí Solar is not far from the prospective home of the proposed Aguirre Offshore Gasport, which would continue Puerto Rico's reliance on imported fossil fuels and further pollute this frontline community (Excelerate Energy, 2017). As an alternative to this fossil fuel project, Coquí Solar aims to develop a small-scale, decentralized solar-powered community center that democratically integrates resident input and other direct forms of involvement (e.g., training in renewable energy literacy and installation), rather than developing 


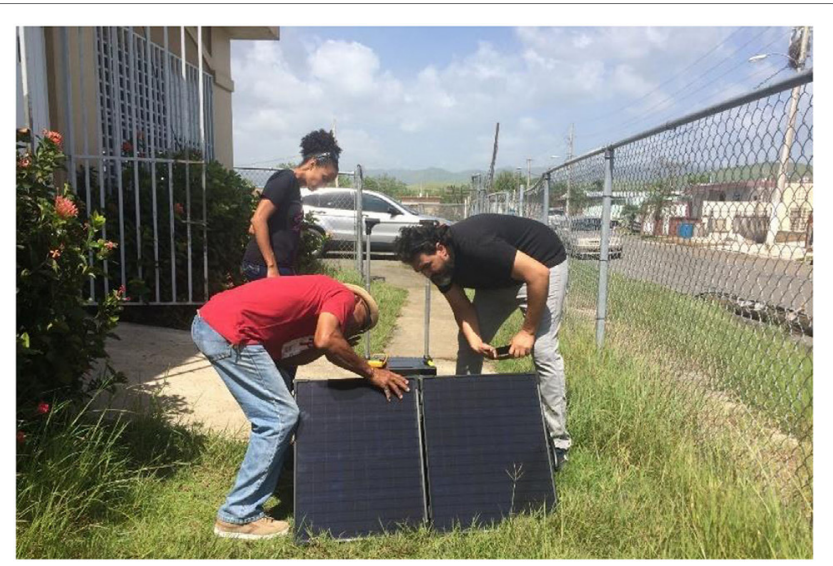

FIGURE 1 | Local residents examine a recently arrived solar generator for their community center in El Coquí, Puerto Rico in October 2017. Photo courtesy of Ruth "Tata" Santiago. All depicted individuals have provided written and informed consent for the publication of their identifiable image.

new or retrofitting already-existing, top-down, centralized infrastructure that depends on imported hydrocarbons from US and Latin American corporations. Those involved with Coquí Solar hope the project will serve as the first community-built, fully solar-powered town in Puerto Rico, exemplifying how the area can move justly and sustainably beyond imported fossil fuels (see Figure 1). Contributing groups include the Junta Comunitaria del Poblado Coquí, Inc. (Community Board of the Coquí Settlement, Inc.), the Iniciativa de Ecodesarrollo de Bahía de Jobos, Inc. (Jobos Bay Eco-development Initiative, Inc.), and INESI members. Additionally, since Hurricane María hit, collaborators have worked with Puerto Rican professors in the US diaspora, including the author, to raise funds for, order, and deliver solar generators to advance the project's larger goals. As collaborator Ruth "Tata" Santiago explains, "Energy is one of the greatest challenges we face. We need to implement energy efficiency (conservation), energy demand management programs, and integrate renewable sources of energy generation, especially rooftop solar.... The energy-democracy challenge is one of the things that energizes me. Injustice energizes me. Working with excluded communities energizes me" (personal communication, Ruth “Tata” Santiago, July 8, 2017).

\section{MOBILIZING FOR AN ANTI-COLONIAL, JUST ENERGY FUTURE}

This essay addresses a multi-pronged energy emergency in Puerto Rico-and its complexities - to contribute to disrupting the underlying infrastructural and other injustices that perpetuate fossil fuel dependency and its uneven impacts. Focusing on Puerto Rico is important for energy democracy scholarship for at least two reasons: (1) it makes the unsustainability of our hydrocarbon frenzy feel urgent, and (2) it evinces that energy transitions must consider the role of energy colonialism in shaping contemporary realities and how to grapple with, and ultimately uproot, relationships grounded in extractivism.
First, the archipelago's energy challenges and its related, disproportionate experiences with environmental degradation and climate disruption make Puerto Rico an apt location for examining the precarity and consequences of carbon-based economies (Pezzullo and de Onís, 2017). Detailed study of Puerto Rico's energy exigencies helps make the need to transition justly and sustainably from high- to low-carbon energy sources feel pressing and vital. In other words, critically engaging Puerto Rico's frontline experiences brings an urgency to the imperative of keeping fossil fuels in the ground and unsettles pervasive complacency by those currently privileged enough to look the other way. While the mainstream news media and US government narratives often limit descriptions to the turmoil faced by Puerto Ricans, many residents and their diasporic counterparts are mobilizing resources to construct alternative energy futures.

Second, though neoliberalism shapes our global unsustainable energy milieu, colonial ideology, discourses, and policies also lock us into our current carbon-fueled crisis (Chakrabarty, 2009; Endres, 2009; Schneider et al., 2016). A study of this Caribbean locale makes the underlying logics of domination and dispossession difficult to ignore and provides possibilities for imagining more just, less exploitative alternatives. Thus, future research on energy policy, discourses, and injustices should foreground the role of energy colonialism and its legacies in shaping deliberations and decision-making processes and how various discursive practices enable and constrain more sustainable energy futures.

While the energy emergencies facing Puerto Rico are, in some ways, very specific to this Caribbean archipelago, the concerns raised in this essay also are relevant whether one lives on an island, on a large land mass, or in a rural or urban area, as humanity confronts the climate change and policy imperative of participating in the "Great Transition" from a fossil fuel, carbon-based economy to a renewable, decentralized, and energy just one (Brown, 2015). Rising and acidifying oceans, desertification, species extinction, and the increasing intensity and frequency of extreme weather events, epitomized by Hurricane María, remind us of the growing urgency posed by our climate crisis and the untenable practices that fuel this reckless trajectory (de Onís, 2012). The alternative path is not easy, and it involves grappling with the tensions of alienation and interconnection, loss and love, crisis and caring, and harm and hope that shape our present moment (Pezzullo and Cox, 2017; Pezzullo and de Onís, 2017). The material sea change linked to global climate disruption already threatens life in disproportionately impacted communities. However, as evinced by different grassroots and academic collaborators in Puerto Rico, a sea change of another kind is possible.

\section{ETHICS STATEMENT}

This study was carried out in accordance with the recommendations of the Indiana University IRB, with written informed consent from all subjects. All subjects gave written informed consent in accordance with the Declaration of Helsinki. The protocol was approved by Indiana University. Research participants provided written and informed consent for their personal details to be disclosed. 


\section{AUTHOR CONTRIBUTIONS}

The author confirms being the sole writer of this work and appreciates contributions from community members in Puerto Rico, whose arguments and experiences inform this article.

\section{REFERENCES}

Atiles-Osoria, J. (2014). Environmental colonialism, criminalization and resistance: Puerto Rican mobilizations for environmental justice in the 21 st century. RCCS Annu. Rev. 6, 3-21. doi:10.4000/rccsar.524

Berman Santana, D. (1996). Kicking Off the Bootstraps: Environment, Development, and Community Power in Puerto Rico. Tucson: The University of Arizona Press.

Bonilla, Y. (2017). Why Would Anyone in Puerto Rico Want a Hurricane? Because Someone Will Get Rich. Washington Post. Available at: https://www. washingtonpost.com/outlook/how-puerto-rican-hurricanes-devastate-manyand-enrich-a-few/2017/09/22/78e7500c-9e66-11e7-9083-fbfddf6804c2_story. html?utm_term $=0.582 \mathrm{a} 00 \mathrm{aca} 853$

Bonilla, Y. (2018). How Puerto Ricans fit into an increasingly anti-immigrant U.S. The Washington Post. Available at: https://www.washingtonpost.com/news/ posteverything/wp/2018/01/19/how-the-u-s-will-replace-immigrant-workers-with-puerto-ricans/?utm_term $=.9 \mathrm{c} 48197 \mathrm{f} 49 \mathrm{db}$

Brown, L. R. (2015). The Great Transition: Shifting from Fossil Fuels to Solar and Wind Energy. New York: WW Norton and Company.

Bullard, R. (1993). Confronting Environmental Racism: Voices from the Grassroots. Boston, MA: South End Press.

Bureau of Labor Statistics. (2017). Puerto Rico. Available at: https://www.bls.gov/ eag/eag.pr.htm

Casa Pueblo. (2016). Sistema de energía solar. Available at: http://casapueblo.org/ index.php/proyectos/sistema-de-energia-solar/

Center for Investigative Journalism. (2017). Nearly 1,000 more people died in Puerto Rico after Hurricane María. Available at: http://latinousa.org/2017/12/07/ nearly-1000-people-died-puerto-rico-hurricane-maria/

Centro. (2017). Estimates of Post-Hurricane Maria exodus from Puerto Rico. Centro. Available at: https://centropr.hunter.cuny.edu/research/data-center/ research-briefs/estimates-post-hurricane-maria-exodus-puerto-rico

Chakrabarty, D. (2009). The climate of history, four theses. Crit. Inq. 35, 197-222. doi:10.1086/596640

Cummins, E. (2017). Should Tesla Rebuild Puerto Rico? Slate. Available at: http:// www.slate.com/articles/technology/technology/2017/10/should_tesla_ rebuild_puerto_rico.html

de Onís, C. (2017a). For Many in Puerto Rico, 'Energy Dominance' Is a Just a New Name for US Colonialism. The Conversation. Available at: https://theconversation.com/for-many-in-puerto-rico-energy-dominance-is-just-a-new-namefor-us-colonialism-80243

de Onís, C. (2017b). Puerto Rican Energy Researchers Excluded from Islands Energy Transition Deliberations. Latino Rebels. Available at: http://www.latinorebels. com/2017/10/16/puerto-rican-energy-researchers-excluded-from-islands-energy-transition-deliberations/

de Onís, K. (2012). 'Looking both ways': metaphor and the rhetorical alignment of intersectional climate justice and reproductive justice concerns. Environ. Commun. J. Nat. Cult. 6, 308-327. doi:10.1080/17524032.2012 .690092

Duany, J. (2002). Puerto Rican Nation on the Move: Identities on the Island and in the United States. Chapel Hill: University of North Carolina Press.

Endres, D. (2009). The rhetoric of nuclear colonialism: rhetorical exclusion of American Indian arguments in the Yucca Mountain nuclear waste siting decision. Commun. Crit. Cult. Stud. 6, 39-60. doi:10.1080/14791420802632103

Excelerate Energy. (2017). Aguirre Offshore GasPort. Available at: http://excelerateenergy.com/project/aguirre-offshore-gasport-2/

Geiling, N. (2017). Secretary Zinke Blames Media for Whitefish Energy Scandal. Think Progress. Available at: https://thinkprogress.org/secretary-zinkeblames-media-for-whitefish-energy-scandal-517a7036a864/

\section{FUNDING}

This project received support from the Organization for Research on Women and Communication, the Waterhouse Family Institute, and the Indiana University Office of Sustainability.

Goldman, J. (2017). Small Company Awarded Big Puerto Rico Contract Has Ties to Trump Administration. CBS News. Available at: https://www.cbsnews.com/ news/whitefish-energy-tiny-montana-company-awarded-huge-puerto-rico-contract-has-ties-to-trump-administration/

Hand, M. (2017). EPA Steps in as Puerto Ricans Grow Desperate for Clean Drinking Water. Think Progress. Available at: https://thinkprogress.org/ epa-focuses-on-puerto-rico-32c0a8862cdf/

Klein, N. (2007). The Shock Doctrine: The Rise of Disaster Capitalism. New York: Picador.

Kolhatkar, S. (2017). Profiting from Puerto Rico's Pain. New Yorker. Available at: https://www.newyorker.com/magazine/2017/11/06/profiting-from-puertoricos-pain

Lloréns, H., Santiago, R., Garcia-Quijano, C.G., and deOnís, C.M.(2018). Hurricane Maria: Puerto Rico's Unnatural Disaster. Soc. Justice Blog. Available from: http://www.socialjusticejournal.org/hurricane-maria-puerto-ricosunnatural-disaster/

McDermott, D. (2017). Energy without Conscience: Oil, Climate Change, and Complicity. Duke, NC: Duke University Press.

Moya, A. (2017). Casa Pueblo Taps Solar Power, Diaspora to Help Communities. Caribbean Business. Available at: http://caribbeanbusiness.com/casa-pueblotaps-solar-power-diaspora-to-help-communities

Noticel. (2017). Gobernador solicita la cancelación del contrato de Whitefish. Available at: http://www.noticel.com/ahora/gobernador-solicita-la-cancelacindel-contrato-de-whitefish/647821638

Pezzullo, P. C., and Cox, R. (2017). Environmental Communication and the Public Sphere, 5th Ed. Thousand Oaks, CA: SAGE.

Pezzullo, P. C., and de Onís, C. M. (2017). Rethinking rhetorical field methods on a precarious planet. Commun. Monogr. 85, 1-20. doi:10.1080/03637751. 2017.1336780

PREC. (2016). Puerto Rico Energy Commission. Available at: http://energia.pr.gov/ datos/distribucion-porcentual-de-la-generacion-de-energia-por-tipo/

PROMESA. (2016). US Congress, House of Representatives, Committee on Energy and Natural Resources, PROMESA (H.R.5278), 114th Congress. Available at: https:// congress.gov/bill/114th-congress/house-bill/4900

Resilient Power Puerto Rico. (2017). Available at: http://resilientpowerpr.org/resilientpr/ Robles, F., and Mazzei, P. (2017). Parts of Puerto Rico Won't Have Power for Eight Months. What's the Hold Up? New York Times. Available at: https://www. nytimes.com/2017/12/23/us/puerto-rico-power-outage.html

Santiago, R., Lloréns, H., Garcia-Quijano, C. G., and de Onís, C. M. (2017). Dispatch from the Frontlines of Puerto Rico in a Post-Maria World. Latino Rebels. Available at: http://www.latinorebels.com/2017/10/09/dispatch-fromthe-frontlines-of-puerto-rico-in-a-post-maria-world/

Schneider, J., Schwarze, S., Bsumek, P. K., and Peeples, J. (2016). Under Pressure: Coal Industry Rhetoric and Neoliberalism. United Kingdom: Palgrave Macmillan.

Wanzer-Serrano, D. (2015). The New York Young Lords and the Struggle for Liberation. Philadelphia, PA: Temple University Press.

Whitefish Energy. (2017). Available at: https://www.whitefishenergy.com/

Conflict of Interest Statement: The author is a member of one of the grassroots organizations discussed in this essay.

Copyright (C) 2018 de Onis. This is an open-access article distributed under the terms of the Creative Commons Attribution License (CC BY). The use, distribution or reproduction in other forums is permitted, provided the original author(s) and the copyright owner are credited and that the original publication in this journal is cited, in accordance with accepted academic practice. No use, distribution or reproduction is permitted which does not comply with these terms. 